\title{
Poverty Reduction through Microfinance Assistance by Banks in Rural Areas -An Analytical study
}

\author{
Dr. G. L. Parvathamma \\ Associate Professor, Department Of Economics, Bangalore University Post Graduate Centre, Kolar-563101.
}

\begin{abstract}
In developing country like India where approximately 400 million people living below or close to the poverty line, could be roughly translated into 75 million household out of which around 60 million are rural household. So poverty in India has predominantly a rural character.

Micro finance has emerged as a needful programme to cater to the needs of the most under privileged people i.e., tribal, Dalits and Women. Micro finance is expected to play a pivotal role in poverty eradication and employment generation. In the present study Emphasis is to be given to analyse the nature of the micro finance activities under taken by the banks, role of banking institutions in rendering micro credit services to the poor people. Efficiency of micro finance provided by the banks and also identifies level of customer satisfaction about micro credit offered by the banks. Further, it concludes that. the most important form of micro finance is credit targeted to poor people who are also talented entrepreneurs. If these people gain access to credit, they will expand their business, stimulate local economic growth. These banks will be able to support their client's efforts to control family risks as well as capitalize on business opportunities. They will offer savings, insurance, remittance services and personal and business loans, to help clients grow their assets while increasing their incomes. The goal of growth and poverty alleviation is now well recognized, so the micro finance is a very good platform for ensuring this by optimizing use of the financial resources and generate the employment potentiality.
\end{abstract}

Keywords: Poverty Reduction, SHGs. business loans

\section{Introduction}

In developing country like India where approximately 400 million people living below or close to the poverty line, could be roughly translated into 75 million household out of which around 60 million are rural household. So poverty in India has predominantly a rural character.

Micro finance has emerged as a needful programme to cater to the needs of the most under privileged people i.e., tribal, Dalits and Women. The major concern today is increasing poverty and there is urgent need of empowering, enabling the most neglected sections of the society through organized support to all poverty alleviation programmes. Micro finance is expected to play a pivotal role in poverty eradication and employment generation. Emphasis here is commercial and co-operative banks provide micro finance services to large number of poor people.Today India is facing major problem in reducing poverty. Millions of rural poor do not have access basic savings and credit services that most people take for granted and these make it much harder for the poor to rise out of poverty. Micro finance is considered one of the most effective and flexible strategies in the fight against global poverty. Micro finance in India started in the early 1980 with small efforts at forming self help groups (SHG) to provide an access to the much needed savings and credit services. The existing credit institutions and the initiatives taken by the authorities have not helped the rural poor to improve their standard and welfare. With regard to the provision of credit there seems to be a big gap between the requirement of rural people and their convenience.

Micro finance provides an opportunity for the banks to search rural poor in groups for extending various financial services and ensure financial inclusion. It should not be viewed as a government problem by the banks but as a desirable long term strategy for growth. India has witnessed tremendous progress in micro financing during the recent years. There is a surge in the investor interest and there has been a phenomenal growth in the number of micro finance institutions (MFI). There are many new entrants in to the sector like private and multinational banks, private equity and venture capital funds, whole sale fund providers rating agencies, international retail institutions etc.The sector has exhibited exponential growth during the last five years. The banking sector has been able to reach approximately 59 million households through SHGs and approximately 9 million other households have been covered by MFIs in the country. 


\section{Review of Literature}

Prof. Neha Patel in his article Micro finance-Strategy for Poverty Alleviation expresses his opinion. i.e., micro finance can help the poor to increase income, build viable businesses and reduce their vulnerability to external shocks. It can be a powerful instrument for self empowerment by enabling the poor, especially women, to become economic agents of change and finally to attain sustainable rural development.. Sreelakshmi and Niranjan Shetty has conducted an experiment about "Empowerment through Micro finance" under this the SHGs are powerful weapons in the hands of NGOs as well as banks. They have to be propelled in the right direction to hit the target in order to bring about a change in the rural economy and empower the rural lives. A holistic development can be brought about by reaching the grass root level of the rural India. "A one-stop shop for financial services to the poor" in this article the authors Dr. Sandip k. Bhatt and Dr. Hetal Jhaveri expresses his opinion i.e., Micro finance is a broad term that includes variety of financial services offered specifically to the poor .Micro finance has been hailed as a new age solution to alleviate poverty and bring economic prosperity to the rural economy. It is true that MFIs contribute to improving lives of the poor people but they a long way to go. Yet, they need to increase their reach by increasing their focus on rural areas and on those who are very poor.Mitali Sen has conducted an experiment about "Assessing Social Performance of Micro finance Institutions in India". Under this the social rating presents a range of information that is relevant to achieving mission and contributing social value. Through defining different dimensions of social performance, the MFIs can themselves manage their social performance and identify the indicators that are relevant to social reporting. It is a process which is much cheaper and faster than impact and also practical for an MFI to implement.

\section{Objectives}

1. To examine the nature of the micro finance activities under taken by the banks.

2. To analyze the role of banking institutions in rendering micro credit services to the poor people.

3. To examine the efficiency of micro finance provided by the bank.

4. Evaluate the level of customer satisfaction about micro credit offered by the banks.

\section{Methodology}

The sample area covered under this study was co-operative and commercial banks in Kolar. 100 respondents were considered for this study. Random sampling technique was used to gether relevant data from universe. Data was collected from co-operative and commercial banks respondents. It is an empirical cum analytical study using survey method. The primary data were collected by use of well structured questionnaire along with personal interview to interact effectively with the respondents for electing wide information. As par as secondary data is concerned that magazine, journals, internet information have been relied up on. The primary data collected on the study were analyses with the help of statistical tools and techniques such as \% ages, averages and likes to make the data presentable in a more effective

\section{Need for micro finance by banks}

There is plenty of scope for the banking sector to play a lead role in the extension of financial services to the rural demanders of credit for various purposes which would also help the banks to increase their business besides spreading their risk. There has been wide recognition of the fact that there is a very good opportunity for banks to do retail loan business .with the growth of the NGOs and SHGs and their linkage with the bankers, there is ample scope to facilitate micro financing activities in the rural areas.

\section{Financial needs of poor people}

In developing economies and particularly in the rural areas, many activities that would be classified in the developed world as financial are not monetized; that is, money is not used to carry them out. Almost by definition, poor people have very little money. But circumstances often arise in their lives in which they need money or the things money can buy.In 'Stuart Rutherford's recent book the poor and their money, he cites several types of needs

$>$ Life cycle needs: such as weddings, funerals, child birth, education, home building, widowhood, old age.

$>$ Personal emergencies: such as sickness, injury, unemployment, theft, harassment or death.

$>$ Disasters: such as fires, floods, cyclones and man made events like war or bulldozing of dwellings.

$>$ Investment opportunities: expanding a business, buying land or equipment, improving housing, securing a job (which often requires paying a large bribe) etc

Poor people find creative and often collaborative ways to meet these needs, primarily through creating and exchanging different forms of non-cash value. Common substitutes for cash vary from country to country but typically include live stock, grains, jewellery and precious metals 


\section{SHGs and reduction of poverty}

Several research studies carried out by NABARD India led to the evaluation of Self-Help Group (SHG)-bank linkage model as a cost-effective mechanism for providing financial services to the unreached and un- served poor. In the year 1992, NABARD introduced SHG linkage scheme with commercial banks, these groups are lent by commercial banks directly or through NGOs. The SHG bank linkage programme is the flagship micro finance information of NABARAD. The bunching of its pilot phase of the SHG bank linkage programme in Feb 1992 could be considered a landmark development in banking with the poor. The informal thrift and credit group, comprising poor people, came to be recognized as bank clients under the pilot phase. The pilot phase was followed by setting up a working group on NGOs and SHGs by the RBI in 1994, which came out wide ranging recommendations of the SHG concept has a potential intervention tool in the strategies of banking with the poor. The RBI accepted most of the major recommendations and advised the banks to consider lending to the SHGs to be part of their mainstream rural credit operations. The members of SHG are encouraged to collect regular thrift on a weekly or fortnightly basis and use the pooled thrift to give interest bearing small loans to needy members.

Micro Finance Profile of the District

\begin{tabular}{|c|c|c|}
\hline Total number of taluk in the district & \multicolumn{2}{|c|}{5} \\
\hline No. of taluk where SHGs exist & \multicolumn{2}{|c|}{114} \\
\hline Total no. of taluk where SHGs are credit linked & \multicolumn{2}{|c|}{4} \\
\hline No. of NGOs in the district & \multicolumn{2}{|c|}{5} \\
\hline No. of NGOs participating in linkage programme & \multicolumn{2}{|c|}{5} \\
\hline No. of additional NGOs to be roped in during 2008-09 & RBs & Coops. \\
\hline Total No. of bank branches in the district & 64 & 34 \\
\hline Of which no. of branches participating in the linkage programme & 64 & 34 \\
\hline No. of additional branches proposed to be roped in during the year & 4 & 6 \\
\hline No. of branches (PACSs actins as SHPI ) & - & - \\
\hline No. of Government/other agencies participating & & 3 \\
\hline No. of Government /other agencies likely to participate & & 2 \\
\hline
\end{tabular}

(Sources:PLP,Shri jayprakash. L. Samudre)

\section{Micro-Finance Institutions - Bank Linkage \\ MFIs in Kolar district are}

$>$ Prithvi Souharda CLA promoted by Prakruthi.

$>$ Dhanalakshmi CLA, SIRDS, Kothaladinne.

$>$ Cauvery Coop Society promoted by BRAES, Kolar.

$>$ RORES in Srinivaspur, AVORD, Lakshmipur, and Citizens, Tayalur.

$>$ Sanghamitra, an NBFC promoted by MYRADA, has begun its operations for financing SHGs in the district. The NBFC has been sanctioned with a revolving fund assistance of Rs. 2.51 crore by NABARD for providing credit assistance to SHGs in 10 districts, including Kolar. The agency has also accessed funds from commercial banks. The recovery performance of SHG financing by Sanghamithra is stated to be $70 \%$ due to financing NGOs having no tract record.

$>$ Gram Vikas (NGO) working in Mulbagal taluk has organised all the groups promoted by it into a federation called Grameena Mahila Okkuta. The SHG Federation is having its own funds contributed by the groups as well as the NGO and meets the credit needs of groups in addition to the assistance from banks. Grameena Mahila Okkuta also works for taking care of the general working of the groups and for channelising other programmes.

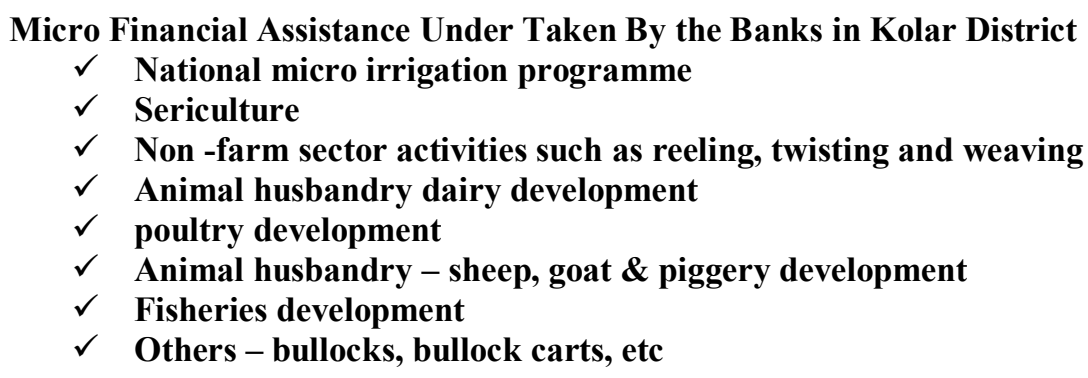


$\checkmark \quad$ Non-farm sector (nfs)

$\checkmark \quad$ Agro \& food processing

$\checkmark$ Other priority sector

$\checkmark$ Professional and self employed:

$\checkmark$ Education loans

$\checkmark$ Housing

$\checkmark$ Consumption loans and others

Primary Data Analysis and Interpretation

Table - 1Gender wise classification of respondents

\begin{tabular}{|c|c|c|}
\hline Gender & Respondents in Number & Percentage (\%) \\
\hline Male & 92 & $92 \%$ \\
\hline Female & 8 & $8 \%$ \\
\hline Total & $\mathbf{1 0 0}$ & $\mathbf{1 0 0 \%}$ \\
\hline
\end{tabular}

\section{Source-field survey}

(The above table is excluding S.H.G. members)

From the survey we can know that the $92 \%$ of male persons and only $8 \%$ of female person are enjoying the loans from various banks (covered under survey)

Table-2 Education wise classification of respondents

\begin{tabular}{|c|c|c|}
\hline Education & Respondents in Number & Percentage (\%) \\
\hline Illiterate & 13 & $13 \%$ \\
\hline Below SSLC & 33 & $33 \%$ \\
\hline SSLC - PUC & 36 & $36 \%$ \\
\hline Graduation & 18 & $18 \%$ \\
\hline Total & $\mathbf{1 0 0}$ & $\mathbf{1 0 0 \%}$ \\
\hline
\end{tabular}

\section{Source-field survey}

It can be seen from the above table from that $13 \%$ of the respondents represent illiterate, $33 \%$ of respondents represent the qualification below SSLC, 36\% of respondents represent the qualification SSLC PUC, and $18 \%$ of respondents are graduates. Thus all 100 respondents were chosen from across different beneficiaries under the study.

Table-3 Classification of respondents on the basis of occupation

\begin{tabular}{|c|c|c|}
\hline Occupation & Respondents in Number & Percentage (\%) \\
\hline Agriculture & 60 & $60 \%$ \\
\hline Tiny business activities & 20 & $20 \%$ \\
\hline Employees & 15 & $15 \%$ \\
\hline Others & 5 & $5 \%$ \\
\hline Total & $\mathbf{1 0 0}$ & $\mathbf{1 0 0 \%}$ \\
\hline
\end{tabular}

Source-field survey

An attempt has been made to find out the proportion of respondents based on their occupation, $60 \%$ of the respondents are engaged in agriculture, $20 \%$ of the respondents are engaged in tiny business activities, $15 \%$ respondents are employees and $5 \%$ of respondents represent others service

Table-4 . Interest rate wise classification of respondent

\begin{tabular}{|c|c|c|}
\hline Interest rate & $\begin{array}{c}\text { Respondents in } \\
\text { Number }\end{array}$ & Percentage (\%) \\
\hline $1-5 \%$ & 56 & $56 \%$ \\
\hline $6-10 \%$ & 20 & $20 \%$ \\
\hline $10-15 \%$ & 24 & $24 \%$ \\
\hline Total & 100 & $100 \%$ \\
\hline
\end{tabular}

Source-field survey

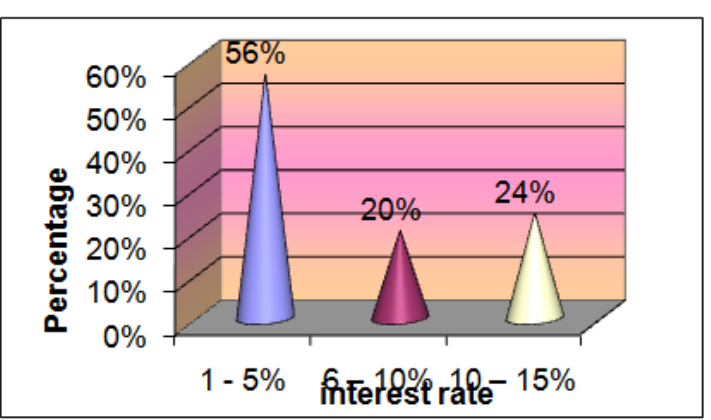

It can be analyzed from the above table $56 \%$ of respondents represent that they have taken loan at the rate of interest $1-5 \%, 20 \%$ of respondents represent that they have taken loan at the rate of interest $6-10 \%$ and $24 \%$ respondents represent that they have taken at the rate of interest $10-15 \%$. 
Poverty Reduction through Microfinance Assistance by Banks in Rural Areas -An Analytical study

Table-5, Sector wise classification of respondents

\begin{tabular}{|c|c|c|}
\hline Sector wise & Respondents in Number & Percentage (\%) \\
\hline Crop loans & 44 & $24 \%$ \\
\hline $\begin{array}{c}\text { Agriculture and allied } \\
\text { activities }\end{array}$ & 22 & $22 \%$ \\
\hline Non farm sector & 10 & $10 \%$ \\
\hline Other priority sector & 24 & $24 \%$ \\
\hline Total & $\mathbf{1 0 0}$ & $\mathbf{1 0 0 \%}$ \\
\hline
\end{tabular}

It can be seen from the above table $44 \%$ of respondent represent that they have taken per the crop loans, $22 \%$ respondents represent that they have taken per the agriculture and allied activities, $10 \%$ respondents represent that they have taken per the non farm sector and $24 \%$ of respondent represent that they have taken for the other priority sector.

Table-6.Loan amount taken by the respondents

\begin{tabular}{|c|c|c|}
\hline Loan amount & Respondents in Number & Percentage (\%) \\
\hline $1000-25000$ & 30 & $30 \%$ \\
\hline $26000-50000$ & 32 & $32 \%$ \\
\hline $51000-75000$ & 20 & $20 \% \mathrm{z}$ \\
\hline $76000-1$ lakh & 12 & $12 \%$ \\
\hline Above 1 lakh & 6 & $6 \%$ \\
\hline Total & $\mathbf{1 0 0}$ & $\mathbf{1 0 0 \%}$ \\
\hline
\end{tabular}

It can be seen in the above table from that $30 \%$ of respondents represent that they have taken the loan amount between $1000-25000,32 \%$ of respondents between $26000-50000,20 \%$ of respondents between $51000-75000,12 \%$ of respondents between $76000-1$ lakh and $6 \%$ of respondents represent that they have taken the loan amount above 1 lakh and respectively.

Table-7.Repayment position of respondents

\begin{tabular}{|c|c|c|}
\hline Repayment position & Respondents in Number & Percentage (\%) \\
\hline Repaying the loan before time & 5 & $5 \%$ \\
\hline Repaying loan in time & 50 & $50 \%$ \\
\hline Delaying loan repayment & 45 & $45 \%$ \\
\hline Total & $\mathbf{1 0 0}$ & $\mathbf{1 0 0 \%}$ \\
\hline
\end{tabular}

From the above statement it can be noticed that the repayment position of the respondents before time is very less i.e., $5 \%$, whereas $50 \%$ of respondents are repaying loan in time and rest of $45 \%$ of the respondents are delaying the repayment of loan.

Table-8 Recovery position of banks

\begin{tabular}{|c|c|}
\hline Banks & $\begin{array}{c}\text { Recovery position } \\
(\%)\end{array}$ \\
\hline Regional rural banks & $88 \%$ \\
\hline (Pragathi Gramin Bank) & $75 \%$ \\
\hline Commercial banks & $28 \%$ \\
\hline PCARDBs & $4 \%$ \\
\hline
\end{tabular}

From the above table it can be noticed that the commercial bank having only $75 \%$ recovery position and regional rural bank having $88 \%$, PCARDBs having $28 \%$ and D.C.C. Bank having less recovery position 
Table-9 Satisfaction level of respondents

\begin{tabular}{|c|c|c|}
\hline Satisfaction level & $\begin{array}{c}\text { Respondents in } \\
\text { number }\end{array}$ & Percentage \\
\hline Full satisfaction & 40 & $40 \%$ \\
\hline Satisfaction & 45 & $45 \%$ \\
\hline Not satisfied & 15 & $15 \%$ \\
\hline Total & $\mathbf{1 0 0}$ & $\mathbf{1 0 0} \%$ \\
\hline
\end{tabular}

The mentioned table clearly shows the satisfactory level of the respondents i.e., $40 \%$ of the respondents are fully satisfied, $45 \%$ of the respondents says only satisfied and $15 \%$ of the respondents says not satisfied.

Table-10 Proportion of Kissan credit cards issued by the banks

\begin{tabular}{|c|r|c|}
\hline Banks & K.C.C. Issued & Percentage \\
\hline Commercial Bank & 247231 & $51 \%$ \\
\hline Pragathi Gramin Bank & 229840 & $48 \%$ \\
\hline D.C.C. Bank & 2955 & $1 \%$ \\
\hline Total & $\mathbf{4 8 0 0 2 6}$ & $\mathbf{1 0 0 \%}$ \\
\hline
\end{tabular}

above table reveals that 247231 (51\%) Kissan credit cards are issued by the Commercial Bank, 229840 (48\%) Kissan credit cards are issued by the Pragathi Gramin Bank and 2955 (1\%) Kissan credit cards are issued by the D.C.C. Bank.

\section{Findings, Suggestions and Conclusions}

Most of the micro finance clients are men's i.e., 92 out of 100 respondents and remaining 8 are women. Most of the bank respondents are farmers that i.e., $65 \%$ the second position is acquired by petty traders and then followed by employee. Most of the respondents that is $56 \%$ respondents are paying interest rate between 1-5\% because govt. has to pay some percentage of interest (subsidy) on loan amount then $20 \%$ respondents paying interest rate between $6-10 \%$ and only $23 \%$ are paying between $10-15 \%$.Most of the respondents that is $44 \%$ respondent are taking crop loan then secondary respondents are take the loan for agriculture, allied activities the this and position acquired by other priority sector. Most of the farmers, they are going to thinking like that the loans may be waiver in future. So they neglecting the repayment of loans, the causes whatever may be the crop failure or unwilling to pay, and also they misusing loans to other purposes ( marriage, festivals)The recovery position of all the banks as on 30-06-2008 has improved mainly on account of farmer's package announced by govt. of India. Recovery of co-operatives increased due to interest waiver scheme announced by govt. of Karnataka.The recovery was poor in respect of KDCCB as on 30-06-2008 mainly on account of continuous draught situation and also on account of confusion prevailing due to wrong propaganda on interest waiver scheme announced by both govt. of India and govt. of Karnataka. Over all recovery performance of bank in the district is hovering around $56 \%$ with RRB branches doing better than other agencies with recovery of $88 \%$. Performance of PCARDBs which was at $28 \%$ due to interest waiver scheme. The decline in advances in respect of co-operatives was due to restrictive rending eligibility on account of poor recovery, the banks could not lend much. The overall growth rate was declined in case of $\mathrm{CBs}$

\section{Following suggestions are provided with the help of the findings.}

Bankers should take special interest on document verification to avoid duplication of documents by the borrowers. The govt. should find out the places where micro finance is need/required and provide sufficient funds to them. Donors and development decision makers should take action in certain directions with the right model for self sufficient financing and effective out reach. Banks should insist that organizations they support price their services at a level that support financial viability. In particular, programs must adjust adequately to the potentially erosive effects of inflation. Adequate and relevant information plan crucial role both in internal management in convincing outsiders (donors, lenders, investors, depositors, regulatory authorities) of the soundness of institutions. Inability to provide such information will slow the development of an institution and limit its access to funding. Banks should insist that supported organization report on their performance according to general understood and accepted standards in away that make subsidies transparent. so. For rural development take special interest to providing and recovering loans provided to the rural people. Interest rate ceilings hurt poor people by preventing microfinance institutions from covering their costs, which chokes off the supply of credit. There is a need for substantial scaling up of micro finance, which includes credit, savings and insurance. Micro finance industry has to find efficient and reliable ways of providing a richer menu of microfinance products. Micro finance institution also needs to enter into a partnership with an information technology service provider in order to successfully set up rural IT networks. There is a need for establishment of a micro finance ombudsman at district levels, which would be useful in preventing usurious practices. The banks, should try to meet the credit requirement of very poor people. 


\section{Conclusion}

The study is about the role of institutions in providing micro financial services. After analyzing and interpreting the data, findings have been enumerated based on this we can conclude that the most important form of micro finance is credit targeted to poor people who are also talented entrepreneurs. If these people gain access to credit, they will expand their business, stimulate local economic growth. These banks will be able to support their client's efforts to control family risks as well as capitalize on business opportunities. They will offer savings, insurance, remittance services and personal and business loans, to help clients grow their assets while increasing their incomes. The goal of growth and poverty alleviation is now well recognized, so the micro finance is a very good platform for ensuring this by optimizing use of the financial resources and generate the employment potentiality. Credit plays a critical role in economic empowerment of the poor and the disadvantaged with this understanding, provision of credit as such and under various credit linked poverty alleviation programmes have been taken up from time to time. The banks will be more successful in the provision if the micro finance activity with careful planning and decision making and banks can overcome any kind of weaknesses.

\section{Bibliography}

[1]. L.M. Bhole, Financial Institutions and Markets.

[2]. Shekhar and Shekar, Banking Theory and Practice, New Delhi.

[3]. Shri Jayprakash .L. Samudre, (DDM NABARD Kolar District), potential linked credit plan.

\section{Field survey}

Magazines and Journals

[4]. Professional Banker

[5]. The Icfaian Journal of Management Research

[6]. Rai Management Journal

[7]. Vikalpa

Websites

[8]. www.pgbankho.com.in

[9]. www.canarabank.com

[10]. www.sbm.com

[11]. Www.answers.com

[12]. www.bangalore@nabard.org 